\title{
Identifying Effective Factors on Nonperforming Loans and its Reduction in the Sixth Development Plan
}

\author{
Hadi Ghaffari* \\ Hossein Ghorbani \\ Department of Economics, Management \& Economics Faculty, Payame Noor University, Tehran, Iran \\ ${ }^{*}$ Corresponding Author
}

\section{Doi:10.5901/mjss.2016.v7n4s2p223}

\begin{abstract}
If the borrower, refuses to returning all or part of the loan, unreturned amount, is called nonperforming assets. Nonperforming assets of the banks is the result of the economic conditions and high levels of inflation and reflects poor performance banks in the management of resources and expenditure.Inceasing the nonperforming assets of banks, will bring decreasing banks facilities, inflation and the underground economy. In this study, to reduce the nonperforming assets of banks in the sixth development plan, for instance, factors affecting nonperforming assets of Melli banks of Markazi Province will be investigated. Independent variables impact , the number of warnings, time of the facilities repayment, amount of credit facilities, interest and inflation rates and dummy variables of collateral, bank supervision and education of borrowers on dependent variable (the amount of nonperforming assets) between the years 1368 to 1388 were investigated using SPSS and by OLS method . Among the above variables, time of the facilities repayment and amount of credit facilities have positive and significant effect on nonperforming assets of Melli Banks and it means the nonperforming assets will increase by its increase.
\end{abstract}

Keywords: Melli bank, decrease of nonperforming assets, the sixth development plan, Markazi province

\section{Introduction}

Recognizing different economic activities and matching any of those activities to engage the banks for granting credit facilities are the main factors in identifying credit priorities to proper implementation of monetary policy and necessity of accuracy of the practice of the low of banking operations without usury. Mentioned priorities in long-term, medium-term and short-term economic plans of the country will be approved by policymakers and what is related to banking system, will be notified to the banks to apply through the money and credit council and the central bank of the Islamic Republic of Iran every year in the form of monetary policy and banks are obliged to take action only "within the limits specified in each economic sector, to pay the credit facility". Respect the mentioned permissible limits will require= the exact knowledge and corresponding any economic activity in the section (Bank Melli Iran, 1990: 15).

Non-performing loans are product of economic conditions and high levels of inflation and they represent the poor performance of banks in the management of their resources and expenditure. It is clear that increase non-performing loans of banks makes the cost of banking resources, lower. And the issue entails reducing the bank facilities and at the national level, a broader consequences, including rising inflation, development of the brokering and underground economy (Amini et al 2010; 71-86)

Macroeconomic conditions and central bank and government intervention in the economy that take shape along with business cycles in the context of the global economy, can stimulate the profitability of companies and individual borrowers of the banks and can affect total facilities and non-performing loans of the banking system. In these circumstances, estimating an appropriate economic model which uses previous information helps a better understanding the relationship between macroeconomic conditions on bank nonperforming assets and credit risk(Heidari et al,2011: 4366.

Not long ago, the Supreme Leader of the Islamic Revolution mandated the general policies of the sixth development plan in a letter to the President. The general policies of the plan, has 80 clauses which its ninth clause points to full and comprehensive supervision of the Markazi Bank on market and monetary, banking and credit institutions and organizing the institutions and non- monetary and fiscal markets to enhance transparency and health and reducing the proportion of non-Current receivables to the facilities(www.farsnews.com)

Accordingly, in this study, we will study the factors affecting banks non-performing loans up with determining the 
influence of these factors, the way to achieve this goal, in sixth development plan, can be smoother. For this purpose, after reviewing the studies conducted on non-performing loans, the impact of each of these factors on non-performing loans will be estimated in a semi-log model, using SPSS software and the method of OLS. Finally, the conclusions and recommendations to reduce non-performing loans of the banks will be investigated.

\section{An Overview of the Literature of the Research and Previous Studies}

\subsection{Internal studies}

Fathpour Kashani's thesis title is the investigation of the status of non-performing loans in Bank Saderat of Iran between the years 1988 to 1997 and providing a suggestion in the context of its reduction. He began his research with these two hypotheses:

1- Correct assessment of granting facilities, is effective in reducing non-performing loans

2- Presence of specialists in the field of granting facilities, is effective in reducing non-performing loans

Then, it pays to test the hypothesis that ultimately, both hypotheses are accepted.

Aghjani Zahed ,in his thesis examines factors affecting the nonperforming loans of Tejarat banks of Gilan province between the years 1981-2002 and he concludes the variables of number of warnings, the term of repayment of installments, the amount of granted facilities and the rate of inflation, have a significant effect on the dependent variable (the amount of non-performing loans) .

Isazadeh and Mansouri Gargari, in an article entitled risk assessment and credit capacity of Tejarat bank customers using neural networks, suggest that non-performing loans have been increased because of increasing credit request from banks. Therefore, the banks to reduce non-performing loans and increase the efficiency of their monetary system have been forced to use various methods such as traditional methods of personal judgment and discriminate analysis to assess credit risk of customers. However, in the current form of payment, most companies and credit customers, acknowledged on inadequacy of the received facilities. So, presenting a model that properly can determine customer ' risk and credit capacity, makes banks able to have optimal use from the collected facilities. For this purpose, in this paper, using the neural network model and balance sheet information of Tejarat bank customers a model for calculating the risk and customer credit capacity is provided (Isa Zadeh and Gargari, 2009: 74-49).Mohammadi Raz in his thesis investigates factors affecting increase of nonperforming assets of Saderat bank of Iran during the years 19862008. He knows the following factors effective on this area.

1. Time series data of interest rate of granted facilities minus inflation

2. The amount of assignment granted facilities adjusted with the implicit price index

3. Adjusted gross domestic income with implicit price index

As a result, it becomes clear that variables of the amount of assignment granted facilities adjusted with the implicit price index and adjusted gross domestic income with implicit price index have significant effect on dependent variable ( the amount of nonperforming assets )

Shabani and Jalali in an article entitled Causes of Nonperforming Assets in Iranian banking system and solutions to improve it, state that according to statistics, in recent years, the ratio of nonperforming assets to total granted facilities, has had a growing trend and continuing the process will have serious risks for the banking system and even the whole economy. Therefore, deal with this problem is very important. Hence, in this paper, after reviewing internal and external experiences about the reasons and ways to deal with nonperforming assets and carrying out field research, more than 30 factors in the incidence of non-performing loans of the country were identified. Moreover, after testing hypothesis, it was concluded that role of intera-organizational factors in forming nonperforming assets is more than inter-organizational factors in Iran's banking system (Shabani and Jalali2001;155-181)

\subsection{Foreign Studies}

Goldstein and Turner, in a study titled banking crises in integrated economies have reviewed origins and policy approaches and causes of the banking crisis that the most important index of them is high ratio of assets, to the balance of the entire facilities. The authors, after studying the various countries have known factors such as macroeconomic instability, excessive lending, the collapse of asset prices and fluctuations of capital flows, heavy intervention of the government, lack of control over relational lending, lack of provision of the necessary measures for financial liberalization, increasing banks' liabilities associated with currency and high maturity of mismatches as the most important reasons for the emergence of banking arrears (Goldstein and Turner,1999:1-67) 
GUO Ning-ning,, in a study as the causes of the emergence of non-performing loans and its solution in commercial banks of China, has divided factors affecting this problem into two categories. In the first category factors such as nonstandard conditions and external factors have been investigated and in the second one the systematic roots of nonperforming loans such as incomplete, decision-making process weak regulatory systems, the process of decentralization executive management, incomplete distribution process of internal revenue, lack of accurate evaluation mechanisms and non-flexible human resources management system have been studied. Eventually, strategies like establishment of centralized and scientific management, creating proper credit culture, a comprehensive reform of the administrative process and creating specialist groups, to solve this problem, have been proposed(GUO Ning-ning, 2007: 13-19)

Gokhan et al have been examined the effect of deposits indefinitely on deferred loans. In 1994 the Turkish government considered performing a deposit insurance through a fixed rate due to the financial crisis which increased non-performing loans. The reason for this was that the banks after the bank deposit insurance, Went to welcome the risk more and moral hazard, and lack of attention to the credit risk of loan applicants led to increase in non-performing loans. In this study, the authors used the Chow test and have concluded that drastic structural changes in outstanding loans, has emerged in 1994. Therefore, using the OLS estimating show that unlimited deposit insurance in Turkey has caused to the emergence of outstanding loans through inflicting damage on allocative efficiency deposits(Gokhan and Bilgin, 2007: 91-96)

\section{Theoretical Framework}

Variables of the study, based on internal and external conducted studies on non-performing loans of the banks, provided as follows:

1. Number of warnings: banks issued a warning for borrowers who have not attempted to repay their loans installments which these warnings can be an appropriate means to achieve non-performing loans. Purpose of issuing a warning, is paying more attention to outstanding assets. In fact, its implementation shows the level of following up of bank's branches for this issue. It seems follow up on demands, in the form of issue a warning, reduces the amount of nonperforming assets.

2. Level of granted facilities : To create necessary facilities for developing various sectors of production, trade and services, banks can provide part of their invest or the required resources as participation(Melli bank of Iran ,1988:247). In other words, the amount of granted facilities is the same amount that the bank pays the person as a loan, in the form of specific contracts and the person is bound to return the same amount, in specified maturities, to the bank. But if a person refrains from returning all or part of this amount to the bank, the amount that has not been returned, is called non-performing loans. The large amount of each installment is the results of huge amount of the loans that can be grounds for pending the claims. In other words, the possibility of the possibility of the pending loans for large sums is much more than outstanding loans with small amounts.

3. Interest rate: One of the most important factors in outstanding bank loans is the interest rate. The higher the rate, the more amount of money he borrower must pay to the bank. Therefore, it can reduce the loan recipients' motivation to settle their debt with the bank. Interest rate for various economic sectors is different For example, interest rates in the housing sector in 2009 were $12 \%$ and in interest-free loan, it was $4 \%$.

4. Duration of facilities repayment: the longer duration of repayment of the facilities, the more interest on the loans is awarded. An obvious example is mortgages in which amount paid by the borrower usually seems to be a double loan due to its many number of installments and therefore high interest rates. Therefore it can be concluded that the probability of pending loans with long payback duration is high. It is worth mentioning the minimum duration of repayment of the facilities is 3 month and the maximum time is 10 years. In addition, this time, to facilitate the purchase of housing, sometimes reaches up to 30 years.

5. inflation rate: inflation is the result of the situation in which the general level of prices are indiscriminately or disproportionately and constantly increases over the time(Tafazoli,1987:439) Until the 1980s, price inflation or continuous increase in the general level of prices was considered a disease. By the way, severe swelling that is known as runaway inflation is extremely destructive economic processes with mutual benefits (Gillis, 2006: 522).

The majority of funds obtained from trading financial assets, is borrowing from the central bank which leads to increase of liquidity and aggregate demand and since "Production of goods and services means aggregate supply do not properly excess Inflation is expected phenomenon (Tavakoli 2007:197t) In general the economy agrees that high rates of inflation and rampant inflation, is due to excessive growth of money (Barro and Grilli, 
1994: 139).This relationship between excessive amount of money and the inflation is as a result of decreasing value for money, and it has been presented among classical economists such as David Hume and David Ricardo ((Blaug, 1997: 129).

Nowadays the main direction of the economy, most of all, is paying attention to make inflation rates slow and steady (Hummel, 2007: 56) because low inflation can reduce difficulties caused by the economic crisis through allowing the market to regulate itself more quickly. It also can reduce the risk from liquidity trap, which prevents the consolidation of monetary policy in the economy (Svensson, 2003: 145-166). Inflation has an effect of distribution of income in the financial market and the labor market as well. Thus in the financial market, cause to transferring income and wealth from lenders to the borrower and in the labor market, it transfers income and wealth from workers to firms or employers (Taghavi, 2011. 223).

Inequality between interest rates and inflation rate, affected the demand for loans. If bank interest rate is lower than inflation rate, the demand for loans will rise. As in recent years, it was always like that. Inflation transfers the real purchasing power relative to goods and services and assets from creditors to debtors. Therefore, get a loan in times of inflation, is affordable. So in terms of inflation, loan recipients received subsidies as much as difference between inflation rate and bank interest rate. During the inflation, the rich become richer and the poor get poorer. Therefore by the an increase of the inflation rate, it is expected that wealthy borrowers, can pay their loans' installment easier but low-income borrowers, having trouble in settlement of their debt with the bank and the possibility of delaying assets in this category of people will rise.

6. Pledge: getting pledge from loans applicants is one of the most effective ways to prevent non-performing loans. Pledge is a tool to be assured of customers' fulfillment commitments. It should be noted that the pledge merely doesn't refer to lease of objective and movable and immovable property . But the nature of the plan or economic activity or any kind of binding documents, contracts and transactions subject property also could be considered as a guarantee of contract implementation. getting pledge also means leas of estate pledge or immovable property. In fact, purpose of banks from objective and material pledges means they tend to have more coverage against unexpected issues in addition to ensuring the proper implementation of plan or economic activity.

7. Bank supervision : Due to the fact that part of the non-performing loans of banks is related to the loans that spent in areas other than what should be spent, it is expected to banks avoid this problem with greater oversight of their loan payments. In other words, banks with more supervision on granted facilities to customers in this respect, that these loans be consumed under the same granted title, to some extent can prevent loans stay pending. Most banking contracts, insist on self-regulatory principle. For example, "in installment sales contract, task of the bank, is buying property and its delivery to the customer. Its selection and installation responsibility will be delegated to the customer. But in some contracts, such as "partnership or transaction with the striking volume of the facilities, Bank directly monitors all activities". Monitoring of operations, causing the issue that consumption of provide facilities, be provided long with the physical progress of plan. It seems facilities that are paid in a monitored way have less delayed repayment.

8. Education level of the borrower: education level customers, partially reflects people reliability and worthiness and if customer education, is associated with facilities consumption, It can show individuals technical competence. The advantage of education compared to general standard of granting banking facilities, is in ease of obtaining. So it is expected a person with high education level, regularly pay their loans installments to the bank, for more familiarity with the rules and regulations and to maintain their reputation as an educated person.

\section{Model}

To investigate factors affecting nonperforming assets, according to mentioned literature and prior theoretical models provided in this area , a semi-logarithmic model has been applied:

(1) $\operatorname{Ln} Y=\alpha_{1}+\alpha_{2} N+\alpha_{3} T+\alpha_{4} C R+\alpha_{5} P P+\alpha_{6} K+\alpha_{7} D_{1}+\alpha_{8} D_{2}+\alpha_{9} D_{3}+V_{i}$

In which $Y$ is the amount of non-performing loans, $N$ is the number of warnings, $T$ is the time of repayment of the loan, $C R$ is the amount of granted facilities, $P P$ is rate of interest , $K$ is the rate of inflation, $D_{1}$ is the type of receiving pledge from the borrower . $D_{2}$ is banks supervision on granted facilities, $D_{3}$ means the education level of the borrower and $V_{i}$ is disturbing element of the model. These models are called semi-logarithmic because only one variables of the model is logarithmic. In these models, slopes of $1 \alpha$ to $9 \alpha$ measures the relative or proportional change in $Y$ for the absolute form in one of independent or virtual variable (Gajrati,1988,211) 


\section{Model Estimation}

Table 1. The coefficients of the model variables

\begin{tabular}{|l|c|c|c|c|c|c|c|}
\cline { 2 - 8 } \multicolumn{1}{c|}{} & B & Std. Error & Beta & t & Sig & Tolerance & VIF \\
\hline Constant & $105 / 15$ & $721 /$ & & $941 / 20$ & 0 & & \\
\hline number of warnings & $077-/$ & $121 /$ & $051-/$ & $636-/$ & $527 /$ & $795 /$ & $258 / 1$ \\
\hline duration of repayment & $01 /$ & $003 /$ & $247 /$ & $059 / 3$ & $003 /$ & $775 /$ & $291 / 1$ \\
\hline amount of facilities & $008-\mathrm{E} 6 / 1$ & 0 & $638 /$ & $134 / 7$ & 0 & $631 /$ & $585 / 1$ \\
\hline Interest rate & $015 /$ & $021 /$ & $057 /$ & $7 /$ & $486 /$ & $771 /$ & $296 / 1$ \\
\hline Inflation rate & $001-/$ & $023 /$ & $004-/$ & $047-/$ & $963 /$ & $858 /$ & $165 / 1$ \\
\hline type of collateral & $236 /$ & $214 /$ & $087 /$ & $105 / 1$ & $273 /$ & $816 /$ & $225 / 1$ \\
\hline Bank supervision & $244-/$ & $191 /$ & $1-/$ & $276 / 1-$ & $206 /$ & $818 /$ & $222 / 1$ \\
\hline Borrowers facilities & $251-/$ & $161 /$ & $115-/$ & $559 / 1-$ & $123 /$ & $923 /$ & $084 / 1$ \\
\hline
\end{tabular}

The coefficient and amount of $t$ in independent and virtual variables are determined according to table 1 through regression estimate using SPSS software, and the regression model is estimated as follow:

(2) $D_{3} 251-D_{2} 244-D_{1} 236+K 001-P P 015+C R 008-E 6 / 1+T 01$ N $+077-/ 1 / 15=L n Y$

$(559 / 1)(-276 / 1)(-105 / 1)(047) \quad(-/ 7)(/ 134 / 7) \quad(059 / 3)(636)(-/ 941 / 20)$

Now we are going to explain the hypotheses the classical linear regression on the model

1. Multicollinearity: in some cases Multicollinearity or the correlation between the independent variables is high and in these cases Inference based on the regression model, can be misleading. if there is linear dependence among independent variables, it is said that there is a Multicollinearity(Zargar 2005:359).hence some indices are used to identify Multicollinearity in SPSS software. These indices are Tolerance and gVIF. therefore to investigate this possibility we will use the following patterns:

$>$ If $\mathrm{VIF}>10$ the Multicollinearity must be investigated

$>$ If tolerance $<0.1$ there is a new problem.

According to the table one, considering that VIF is less than 10 and tolerance is higher than 0.1 , there is no possibility of Multicollinearity in data. Therefore, there is no need to investigate the Multicollinearity .

2. Autocorrelation: the presence of autocorrelation in disturbing $\left(\mathrm{U}_{i} U_{j}\right)$ Violates one of the classical assumptions of linear regression. Therefore, to explore the autocorrelation, the Durbin-Watson test is used. Hypotheses are as follow:

(3) $H_{0}: \operatorname{cov}\left(U_{i} U_{j}\right)=0$

$H_{1}: \operatorname{cov}\left(U_{i} U_{j}\right) \neq 0$

In which $\mathrm{H}_{0}$ means the absence of autocorrelation and $\mathrm{H}_{1}$ means the presence of autocorrelation. Since the Durbin-Watson statistic is $942 / 1$. According to Durbin-Watson statistic table, $\mathrm{H}_{0}$ as a meaning of lack of autocorrelation is accepted.

Table 2. Summary of the model

\begin{tabular}{|c|c|c|c|c|c|}
\hline Model & R & R Square & Adjusted R Square & Std. Error of the Estimate & Durbin-Watson \\
\hline $801 /$ & $641 /$ & $601 /$ & $69087 /$ & $942 / 1$ \\
\hline
\end{tabular}

References: results of the study

3. The variance anisotropy: One of the assumptions that are expressed about the error terms in the regression is that variance of errors has constant values for the independent variable values. For this purpose, we will draw the fitted values diagram against the remaining value. If the values revolve around zero line, and be scattered and do not have process. Variances are matched that according to the chart below shows the variances are identical. 


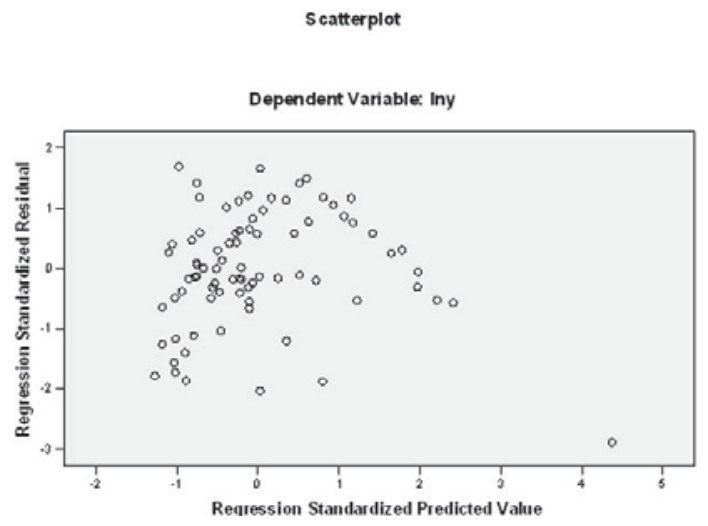

Diagram 1. The heterogeneity of variance

In this section, the effect of independent and virtual variables on the dependent variable (The amount of non-performing loans) has been considered. According to the coefficients table, column B shows virtual and independent variables, coefficients, column $\mathrm{t}$, and sign test the following hypothesis:

(4) $H_{0}: B=0$

$H_{1}: B \neq 0$ Hypotheses $H_{0}$ indicates there is no any significant relationship and $H_{1}$ shows a significant one between independent or virtual variables with the dependent variable.

1. The effect of number of warnings: according to table we have $t=-/ 636$ and sig $=/ 527$. As the amount of sig is more than 0.5 so it indicates that, there isn't any significant effect between number of warnings and the amount of nonperforming loans. Means the hypotheses $\mathrm{H}_{0}$ based on the lack of relationship is accepted.

2. The effect of duration of loan repayment: According to table, we have t -3.59 and sig -003 . As the amount of sig is less than 0.5 so it indicates that, there is significant effect between duration of loan repayment and the amount of nonperforming loans. Means the hypotheses $\mathrm{H}_{0}$ based on the lack of relationship is rejected.

The coefficient of duration of repayment of the loan is equal to $3 a-101$. The positive sign is indicative of a positive and direct relationship between independent variable of the duration of loan repayment and the dependent variable of the amount of non-performing loans. In other words, it can be guess that the more duration of repayment of the loan, the more amounts of non-performing loans we will have.

3. The effect of granted facilities : According to table, we have t-7.134 and sig - 0 . As the amount of sig is less than 0.5 so it indicates that, there is significant effect between granted facilities and the amount of nonperforming loans. Means the hypotheses $\mathrm{H}_{0}$ based on the lack of relationship is rejected.

The coefficient of granted facilities is equal to $008-\mathrm{E} 6 / 1={ }_{4} \alpha$. The positive sign is indicative of a positive and direct relationship between independent variable of granted facilities and the dependent variable of the amount of non-performing loans. In other words, it can be guess that the more granted facilities, the more amounts of non-performing loans we will have.

4. The effect of Interest rate: According to table, we have $t-17$ and sig -/486. As the amount of sig is more than 0.5 so it indicates that, there is not any significant effect between interest rate and the amount of nonperforming loans. Means the hypotheses $\mathrm{H}_{0}$ based on the lack of relationship is accepted.

5. The effect of inflation rate: According to table, we have t-047 and sig -/963. As the amount of sig is more than 0.5 so it indicates that, there is not any significant effect between inflation rate and the amount of nonperforming loans. Means the hypotheses $\mathrm{H}_{0}$ based on the lack of relationship is accepted.

6. The effect of collateral type: According to table, we have t-1.105 and sig-273. As the amount of sig is more than 0.5 so it indicates that, there is not any significant effect between collateral type and the amount of nonperforming loan. Means the hypotheses $\mathrm{H}_{0}$ based on the lack of relationship is accepted. Thus, it can be concluded that the difference between received collaterals, means valid and personal promissory notes and civilian collateral was not significant as the supporting of repayment of the facilities.

7. The effect of bank supervision: According to table, we have t-1.276 and sig - /206. As the amount of sig is more than 0.5 so it indicates that, there is not any significant effect between the virtual variable of bank 
supervision and the amount of nonperforming loan. Means the hypotheses $\mathrm{H}_{\mathrm{o}}$ based on the lack of relationship is accepted.

8. The effect of the borrowers' education: According to table, we have t-1.559 and sig -/123. As the amount of sig is more than $0.5 \mathrm{so}$ it indicates that, there is not any significant effect the virtual variable of the borrowers' education and the amount of nonperforming loan. Means the hypotheses $\mathrm{H}_{0}$ based on the lack of relationship is accepted.

\section{Conclusions and Recommendations}

The findings of this study indicate that two variables of duration of repayment of loans and credit facilities have significant and direct effect on the dependent variable of nonperforming assets. In other words, amount of nonperforming assets will increase by increasing the duration of repayment of the loan or credit facilities .

In the end, the following suggestions to reduce nonperforming assets of bank are provided:

1. Due to the significant impact of duration of repayment of loans on the dependent variable (amount of nonperforming loans) and direct relationship between these two variables, to decrease the non-performing loans it is recommended to decrease the duration of repayment of loans. Since more interest will belonged to the loans with longer installments. It means paying more form the borrower to the bank, can increase the nonperforming loans.

2. Due to the significant impact of the amount of granted facilities on non-performing loans and direct relationship between these two variables loans it is recommended to decrease the amount of loans given to borrowers because increasing the amount of each installment, provides grounds for pending claims. Thus, reducing the amount of loan payments, not only can help reduce non-performing loans, it also lead to lower inflation.

3. Establishment of private companies to receive the non-performing loans and hiring skilled and trained people in this field can reduce the non-performing loans and it can help reducing the unemployment rate through job creation.

\section{References}

Aghajani,Zahed,Omid(2003)investigating factors affecting increase of nonperforming assets of Gilan Tejarat bank. Master's Thesis, Faculty of Human Sciences: Arak Islamic Azad University.

Amini,Alireza,Haghighat,Aliand Hemmati,Fatemeh (2010) Review and analysis of non-performing loans of the banking network of Qazvin province: Challenges and Solutions ", Economic Journal, p86-71.

Bank Melli Iran (1990), domestic banking 1, Tehran: Department of Education and Management.

Bank Melli Iran (1990), The executive Instructions transactions and credit facilities, Tehran: Department of Education and Management.

Tafazoli,Fereydoon(1987) Macroeconomic, Tehran: Ney publication.

Taghavi,Mahdi,(2011) Macroeconomic, Tehran, Payam Noor university.

Tavakoli,Ahmad(2007) Public finance, Tehran: The study and designing organization of Humanities books for University

Heidari,Hadi,Zavarian,Zahra.Noorbakhsh,Iman (2011) "The effect of macroeconomic indicators on non-performing loans of banks", Economic Research, pp66-43

Zargar,Mahmood(2005) Comprehensive Guide 13 SPSS, Tehran: Behineh publication

Shabani,Ahmd,Abdalhosein(2011) "The reasons for the spread of non-performing loans in the banking system of Iran and some solutions to rectify it", planning and budgeting, pp181-155.

Isa zade,Saeed and Mansouri gargari,Hamde(2009) risk assessment and TEJARAT BANK customer's credit capacity using neural networks, strategic management research, pp74-49.

Fathpour Kashani,Reza(1988) Check the status of non-performing loans in the bank Saderat Iran and offering suggestions for reducing it, Master Thesis, Faculty of Human Sciences Islamic Azad University of Arak

Gajerrati,Damoodar(1988) Econometric principles, Hamid Abrishami, Volume I, Tehran: Tehran University

Gillis, Malcolm and others (2006), economic development, Gholamreza Azad, Tehran: Ney publication.

Mohammadiraz,Mahdi(2009) Factors affecting increase of non-performing loans of Bank Saderat Iran, Master Thesis, Faculty of Human Sciences: Arak Islamic Azad University.

Barro, Robert and Grilli Vittorio (1994), European Macroeconomics, London, Macmillan press Ltd.

Blaug, Mark (1997), Economic Theory in Retrospect, London, Cambridge university press.

Gokhan, Karabulut and Huseyin Bilgin, Mehmet (2007), "Sources of non performing loans in Turkish banking system", Journal of business and economics research, Vol.10, No.5, PP.91-96.

Goldstein, Morris and Turner, Philip (1996), Crises in emerging economies: origins and policy options, Bank for International Settlements, Monetary and Economic Department.

GUO Ning-ning (2007), "Causes and solutions of non performing loan in Chinese commercial banks", Chinese business review, Vol.6, 
No.6, PP13-19.

Hummel, J.R (2007), "Death and taxes, including inflation: The public versus Economists", Econ journal watch, Vol.4, No.1, P56.

Svensson, E.O (2003), "Escaping from a liquidity trap and deflation: The foolproof way and others", Journal of economic perspectives, Vol.17, No.4, PP145-166. 